\title{
Internal consistency and accuracy of Interpersonal Support Evaluation List (ISEL-40) in mothers of healthy children and those with a medical history
}

\author{
Anna Aftyka ${ }^{1, A-C, E-F}$, Ilona Rozalska ${ }^{1, B, E-F}$, Aleksandra Pawlak ${ }^{1, B-C}$, Anna Mazur ${ }^{2, C, F}$, Anna Bednarek ${ }^{3, E-F}$, \\ Danuta Zarzycka ${ }^{3, A, D, F}$ \\ ${ }^{1}$ Department of Anaesthesiological and Intensive Care Nursing, Faculty of Health Sciences, Medical University, Lublin, \\ Poland \\ 2 Department of Neuro-Rehabilitation, Institute of Rural Health, Lublin, Poland \\ ${ }^{3}$ Department of Pediatric Nursing, Faculty of Health Sciences, Medical University, Lublin, Poland \\ A - Research concept and design, B - Collection and/or assembly of data, C - Data analysis and interpretation, \\ $D$ - Writing the article, $E$ - Critical revision of the article, $F$ - Final approval of article
}

Aftyka A, Rozalska I, Pawlak A, Mazur A, Bednarek A, Zarzycka D. Internal consistency and accuracy of Interpersonal Support Evaluation List (ISEL-40) in mothers of healthy children and those with a medical history. Ann Agric Environ Med. 2019; 26(1): 85-91. doi: 10.26444/aaem/91783

\begin{abstract}
Introduction and objective. The aim of the study was assessment of the internal consistency and accuracy of the Interpersonal Support Evaluation List - 40 v. GP (ISEL-40 v. GP) in a group of mothers of healthy children and in a group of mothers of children with a medical history, and presentation of the initial research results.

Materials and method. A group of 230 mothers were involved in the research: 57 mothers of healthy children, 26 mothers of infants with a perinatal medical history, as well as 147 mothers of hospitalized children. The method of a diagnostic survey with standardized tools, such as the Interpersonal Support Evaluation List (ISEL-40 v. GP), Hospital and Anxiety Depression Scale (HADS) and the authors' own questionnaire was utilized.

Results. Analysis of the research results suggests satisfactory internal consistency of the ISEL-40 v. GP in the researched group ( $a=0.86$ ). It was also noticed that internal consistency of the subscales varied. The subscales of tangible support $(a=0.79)$ and belonging support $(a=0.73$ ) obtained acceptable values. Internal consistency of self-esteem support ( $a=0.51$ ) and appraisal support $(a=0.62)$ was too low to be recommended for individual and scientific use. An attempt to modify the number of items did not come up to expectations in terms of the subscales internal consistency. Social support in mothers of healthy and ill children was moderate (29.92 - 33.45 points) and no statistically significant differences in their perception of the support were observed.

Conclusions. In the research on a group of mothers of healthy and ill children it is recommended to use only a social support indicator based on the general result of the ISEL-40 v. GP. Further research aimed at verification of the theoretical structure of the Polish version of the ISEL-40 v. GP is advised.
\end{abstract}

Key words

social support, Interpersonal Support Evaluation List, ISEL-40, social support of mothers

\section{INTRODUCTION}

Long-term and multifaceted research has proved a relationship between social support and mental as well as physical health in numerous and diverse populations $[1,2,3,4,5]$. Social support affects health through a direct effect on physiologic processes, such as cardiovascular reactivity, functions of the immune system, and inflammation [6]. Indirect mechanisms that involve a link with behavioural $[7,8]$ and psychological factors such as resistance to depression [9] or cognitive functions [10], which rebound on physiological processes $[11,12]$ are also well documented. A low level of social support is connected with the prevalence of various diseases, including diabetes, cardiovascular diseases, arthritis, chronic pain, mood disorders and anxiety $[3,5,13]$ as well as poor adaptation to such diseases as cancer, arthritis, multiple

Address for correspondence: Danuta Zarzycka, Department of Pediatric Nursing, Faculty of Health Sciences, Medical University of Lublin, Lublin, Poland e-mail: danuta.zarzycka@umlub.pl

Received: 11.03.2018; accepted: 28.05.2018; first published: 23.08.2018 sclerosis, HIV/AIDS [14, 15, 16, 17], and higher death rate due to various causes [4]. Internet users' social support does not lose its properties as some sparse research shows [18].

Social support is connected with gender. Females provide greater social support, are better providers of support and engage more in creating and maintaining social networks. They more often actively seek social support to cope with stress [19]. Taylor et al. suggested that gender differences in terms of social support can result from the biological difference between men and women. Women's behavioural reactions to stress follow the pattern of 'square up and make friends.' Therefore, women's care involves caring actions aimed at protecting oneself and one's offspring, which promotes safety and reduces anxiety. Making friends creates and maintains social ties that can facilitate the process. The bio-behavioural pattern, which is the basis for the tendency to make friends, seems to draw from the system of attachment and care, and the neuroendocrine evidence from research on animals and humans suggests that oxytocin combined with female reproductive hormones and endogenic opioids are 
the essence of friendship [20]. Further research is necessary to explain the influence of ovarian hormones on stress and immune reactions in the course of reproductive stages, including the monthly period, pregnancy and perimenopause [19]. Distinct and multifaceted differences in biological gender and in psychological gender [21] in response to stress suggest that they result from a strong evolutionary pressure. Most probably they are caused by the need for protecting the foetus from the adverse effect of stress in mothers [22]. Other authors claim that women's care and making friends are not reactions to stress, but are rather a persistent maternal feature, whereas mothers' anxiety and depression result from their increased sensitivity to situational stress such as illness. Research results suggest that supporting interventions ought to be aimed mainly at mothers [23]. Nevertheless, some research indicates that there is no link between the gender of the researched individuals and their perception of support provided by nursing staff [24].

Social support of the parents of chronically ill children (e.g. suffering from diabetes mellitus) can be recognized as a strategy for improving their quality of life, both at the beginning and in the course of the disease. The child and family are treated as a system which should be supported by the primary network of social support [25] which should be supplemented by professional care [26]. Research shows that the mothers' perception of the severity of the disability in epileptic children was negatively correlated with the perceived social support which, in turn, was negatively correlated with the severity of anxiety and depression in the mothers [27]. According to the research, low social support in the families of children with hearing impairment and behavioural problems, as well as (affected by) domestic violence, was a predictor of mental diseases in the mothers [28].

Numerous tools have been utilised to measure social support in research projects. However, the 40-item Interpersonal Support Evaluation List, General Population (ISEL-40 v. GP) [29] is probably the most common. A shortened version of the tool, the ISEL-12 [30] and the broadened version for students, the ISEL-48 v. Coll. [29], are widely accepted as a measure of the availability of functional social support [31]. The respondents point to what extent the items describing the availability of various forms of social support are true or false in their lives. No time framework or referential period of time for the chosen answers is used. The basis for developing the group of ISEL scales was the assumption that defines social support as a resource based on the relation of an individual with the social environment, which involves direct protection from stressors, or the modification of the perception of stressful situations, or as a buffer for the negative consequences of stressful events. Thus, social support is manifested only when such a negative situation occurs $[29,30]$. The theoretical grounds of the questionnaire derive from the buffer concept of social support and Cohen and McKay's hypothesis. The former highlights that the perception of the availability of support from the environment constitutes a buffer that mitigates the negative effects of stress. The latter hypothesis assumes that social support has the buffer effect only when central needs created as a result of stressful events are fulfilled [29, 30].

The ISEL- 40 v. GP consists of 40 dichotomous items which give a total result that describes the general perception of social support availability. The tool enables the measurement of 4 dimensions of support, i.e. self-esteem, tangible support, belonging support and appraisal support. Self-esteem support (cognitive-appraising) is supposed to measure the perceived availability of persons with whom an individual can talk about her/his difficulties, problems which favour a better understanding of the individual's situation. Self-esteem support also involves feedback on the effectiveness of the individual's actions. Tangible support is aimed at measuring perceived availability of material support, i.e. financial but also concrete help for the person in need, e.g. providing medications, equipment. Appraisal support measures perceived availability of positive comparison with others. It gives an individual a sense of acceptance and appreciation. Belonging support is supposed to measure perceived presence of persons (members of the support network) with whom an individual can spend time and share the feeling of solidarity $[29,33]$.

The results of the psychometric properties of the original version of ISEL-40 v. GP proved its good internal consistency, test-retest reliability and common accuracy [29], as did the Polish adaptation of the tool. Both the research of the original scale and the adaptation and validation of its Polish version were performed on a sample of students [34, 35]. Determination of the psychometric properties of the ISEL$40 \mathrm{v}$. GP on a sample of adult women who are mothers will improve the quality of scientific research in this group.

\section{OBJECTIVE}

The aim of the study was assessment of the internal consistency and accuracy of the social support scale (ISEL-40 v. GP) on a group of mothers of healthy children and those with a medical history, and presentation of the initial research results.

\section{MATERIALS AND METHOD}

A total of 230 mothers of children aged from $0-18$ years participated in the research. They included 57 mothers of healthy children, 26 mothers of infants with a perinatal medical history and 147 mothers whose children have been treated in hospital. Having been informed about the aim and course of the research, the mothers were asked to sign informed consents to participate in it. Next, they were given the questionnaires in addressed envelopes, together with instructions on how to return the questionnaires. The mothers' participation in the survey was anonymous. The research was carried out in eastern Poland from 1 September 2016 to 31 December 2017. The research project was approved by the Bioethics Commission of the Medical University in Lublin, Poland (No. KE-0254/119/2015).

The following instruments were utilized in the course of the research:

1. The Interpersonal Support Evaluation List, General Population (ISEL-40 v. GP) by S. Cohen, and its Polish adaptation by D. Zarzycka et al. The version of the scale for the general population comprises 40 dichotomous items with a choice of 2 answers: 'probably true' or 'probably false.' The tool measures the opinion of those surveyed on the potential of receiving social support. Psychometric properties of the ISEL-40 v. GP in the afore-mentioned adaptation are comparable with the results obtained by Cohen et al. which show generally acceptable criteria accuracy and reliability [34]. 
2. The Hospital Anxiety and Depression Scale (HADS) by Zigmong and Snaith (1983) was used to measure the severity of the symptoms of depression and anxiety [36]. This is a self-descriptive scale consisting of 14 items, and adapted into Polish by Majkowicz and de WaldenGałuszko [37, 38]. The internal consistency ratio for the anxiety subscale Cronbach's alpha equaled 0.87 , and for the depression subscale Cronbach's alpha was 0.89 .

The mothers surveyed were also asked to complete metrics with the socio-demographic data of the respondents.

Statistical analysis. The characteristics of the research sample were developed on the basis of the analysis of the percentage distribution, frequency of qualitative variables, and for the quantitative variables also on the values of descriptive statistics - mean, standard deviation, minimum and maximum. Internal consistency was estimated with the use of Cronbach's a coefficient. Dependence between quantitative variables was determined by means of Speraman's rank correlation coefficient. The Kruskal-Wallis test by ranks was utilised to assess the differences in the level of support in separate groups of mothers. Statistical analysis was performed with SPSS v. 21 software.

Validation sample characteristics. A total of 230 mothers of children aged from 0-18 years participated in the research. They included 57 mothers of healthy children, 26 mothers with perinatal medical history, as well as 147 mothers of children treated in hospital (50 mothers whose children were treated in the Neonatal Intensive Care Unit (NICU), 31 mothers of children treated in the Paediatric Intensive Care Unit (PICU), and 66 mothers of children treated in the Paediatric Haemato-Oncology Unit (PHOU). The age of the respondents ranged from 20-53 years of age (mean age 34 ). The majority of those surveyed had higher education $(n=138$. $60.0 \%)$ and lived in urban areas $(n=131,57.0 \%)$. Married women were dominant $(n=196,85.2 \%)$. More than half of the respondents stated that their financial status enabled them to live comfortably ( $n=143,62.2 \%)$. Every fifth woman claimed that she suffered from a chronic illness $(n=40,20.9 \%)$. Most frequently, they had 2 children $(n=97,42.7 \%)$, and a slightly smaller number of them had 1 child $(n=82,36.1 \%)$ (Tab. 1$)$.

Cronbach's alpha for the ISEL- 40 v.GP is 0.86 . Cronbach's alpha coefficient for the original subscales of the ISEL-40 v.GP was, respectively, 0.79 for Tangible Support, 0.73 for Belonging Support, 0.51 for Self-Esteem Support and 0.62 for Appraisal Support (Tab. 2).

Due to the low value of Cronbach's alpha, an attempt to verify items that constitute the ISEL-40 v.GP was made to improve internal consistency of the entire scale and its subscales. Revision of the items that make up the scale and the removal of 8 items of the tool $(1,4,6,8,22,24,36,40)$ only slightly improved its internal consistency ( $\alpha=0.87)$. In the case of the Tangible support subscale, no removal of any items improved the internal consistency of the tool $(\alpha=0.79)$. The Belonging support subscale had a slightly higher internal consistency $(\alpha=0.75)$ after 2 items were removed: item number 6 ('No one I know would throw a birthday party for me') and item number 22 ('Most people I know do not enjoy the same things that I do'). The Self-esteem subscale showed higher, although still not satisfactory, internal consistency $(\alpha=0.62)$ after removal of item number 4 ('In general, people
Table 1. Characteristics of the researched group

\begin{tabular}{|c|c|c|c|}
\hline & & Frequency & Percentage \\
\hline \multirow{5}{*}{ Group } & $\begin{array}{l}\text { Mothers of children suffering from } \\
\text { neoplastic diseases }\end{array}$ & 66 & 28.7 \\
\hline & Mothers of children treated in NICU & 50 & 21.7 \\
\hline & Mothers of children treated in PICU & 31 & 13.5 \\
\hline & $\begin{array}{l}\text { Mothers of children with perinatal } \\
\text { medical history }\end{array}$ & 26 & 11.3 \\
\hline & Mothers of healthy children & 57 & 24.8 \\
\hline \multirow{3}{*}{ Education } & Primary or vocational & 30 & 13.0 \\
\hline & $\begin{array}{l}\text { General secondary, Vocational } \\
\text { secondary, Post-secondary }\end{array}$ & 62 & 27.0 \\
\hline & Higher & 138 & 60.0 \\
\hline \multirow{2}{*}{$\begin{array}{l}\text { Place of } \\
\text { residence }\end{array}$} & Urban areas & 131 & 57.0 \\
\hline & Rural areas & 90 & 39.1 \\
\hline \multirow{4}{*}{ Marital status } & Married & 196 & 85.2 \\
\hline & Single & 20 & 8.7 \\
\hline & Divorced & 9 & 3.9 \\
\hline & Widowed & 4 & 1.7 \\
\hline \multirow{4}{*}{ Material status } & Sufficient to lead a very good life & 26 & 11.3 \\
\hline & Sufficient to lead a good life & 143 & 62.2 \\
\hline & Suffcient to lead a modest life & 52 & 22.6 \\
\hline & Sufficient to lead a very modest life & 5 & 2.2 \\
\hline \multirow{2}{*}{$\begin{array}{l}\text { Medical history } \\
\text { of chronic } \\
\text { diseases }\end{array}$} & No & 181 & 78.7 \\
\hline & Yes & 48 & 20.9 \\
\hline \multirow{7}{*}{$\begin{array}{l}\text { Number of } \\
\text { children }\end{array}$} & 1 & 82 & 36.1 \\
\hline & 2 & 97 & 42.7 \\
\hline & 3 & 39 & 17.2 \\
\hline & 4 & 3 & 1.3 \\
\hline & 5 & 1 & 0.4 \\
\hline & 6 & 2 & 0.9 \\
\hline & 7 & 2 & 0.9 \\
\hline
\end{tabular}

Table 2. Internal consistency analysis of the original ISEL-40 and its subscales

\begin{tabular}{lccc}
\hline Scale & $\begin{array}{c}\text { Number } \\
\text { of items }\end{array}$ & $\begin{array}{c}\text { Items that constitute } \\
\text { the scale/subscale }\end{array}$ & $\begin{array}{c}\text { Cronbach's } \\
\text { alpha } \\
\text { coefficient }\end{array}$ \\
\hline ISEL-40 v.GP & 40 & $1-40$ & 0.86 \\
\hline Tangible support & 10 & $3,7,11,15,19,23,27,31,35,39$ & 0.79 \\
\hline Belonging support & 10 & $2,6,10,14,18,22,26,30,34,38$ & 0.73 \\
\hline Self-esteem support & 10 & $4,8,12,16,20,24,28,32,36,40$ & 0.51 \\
\hline Appraisal support & 10 & $1,5,9,13,17,21,25,29,33,37$ & 0.62 \\
\hline
\end{tabular}

do not have much confidence in me', item number 8 ('Tere is someone who takes pride in my accomplishments', item number 24 ('am more satisfied with my life than most people are with theirs', item 36 ('I am closer to my friends than most other people are to theirs' as well as item number 40 ('I am as good at doing things as most other people are'). In the case of the Appraisal subscale, removal of the first item ('There is at least one person I know whose advice I really trust') results in a slight improvement in the subscale's internal consistency, which, however, still remained lower than expected. Analysis of the internal consistency of the revised version of the ISEL40 v.GP and its revised subscales is presented in Table 3. 
Table 3. Analysis of internal consistency of the revised version of the ISEL-40 v.GP and its revised subscales

\begin{tabular}{lcccc}
\hline Scale & Number of items & Items included in the scale/subscale & Items removed from the original scale/subscale & Cronbach's alpha coefficient \\
\hline ISEL - R & 32 & $2-3,5,7,9-21,23,25-35,37,39-40$ & $1,4,6,8,22,24,36,40$ \\
\hline Tangible support & 10 & $3,7,11,15,19,23,27,31,35,39$ & - & 0.87 \\
\hline Belonging support - R & 8 & $2,6,10,14,18,26,30,34,38$ & 6,22 \\
\hline Self-esteem support - R & 5 & $12,16,20,28,32$ & $4,8,24,36,40$ \\
\hline Appraisal support - R & 9 & $5,9,13,17,21,25,29,33,37$ & 1 & 0.75 \\
\hline
\end{tabular}

$\mathrm{R}$ - revised version

Table 4. Statistics of the items of the Interpersonal Social Support List (ISEL-40 v. GP)

\begin{tabular}{|c|c|c|c|c|}
\hline & $\begin{array}{l}\text { Scale's mean } \\
\text { after item } \\
\text { removal }\end{array}$ & $\begin{array}{l}\text { Scale's variance } \\
\text { after item } \\
\text { removal }\end{array}$ & $\begin{array}{l}\text { Correlation } \\
\text { item - general } \\
\text { result }\end{array}$ & $\begin{array}{l}\text { Cronbach's } \\
\text { alpha after } \\
\text { item removal }\end{array}$ \\
\hline ISEL_1 & 31.46 & 35.759 & 0.135 & 0.863 \\
\hline ISEL_2 & 31.66 & 33.175 & 0.553 & 0.855 \\
\hline ISEL_3 & 31.52 & 34.525 & 0.425 & 0.859 \\
\hline ISEL_4 & 31.54 & 35.651 & 0.082 & 0.864 \\
\hline ISEL_5 & 31.53 & 34.319 & 0.474 & 0.858 \\
\hline ISEL_6 & 31.52 & 34.810 & 0.349 & 0.860 \\
\hline ISEL_7 & 31.51 & 34.643 & 0.425 & 0.859 \\
\hline ISEL_8 & 31.51 & 34.535 & 0.417 & 0.859 \\
\hline ISEL_9 & 31.59 & 34.370 & 0.360 & 0.859 \\
\hline ISEL_10 & 31.48 & 35.045 & 0.379 & 0.860 \\
\hline ISEL_11 & 31.53 & 34.692 & 0.365 & 0.859 \\
\hline ISEL_12 & 31.81 & 33.988 & 0.323 & 0.860 \\
\hline ISEL_13 & 31.54 & 34.319 & 0.453 & 0.858 \\
\hline ISEL_14 & 31.68 & 33.629 & 0.443 & 0.857 \\
\hline ISEL_15 & 31.54 & 34.436 & 0.419 & 0.858 \\
\hline ISEL_16 & 31.62 & 33.912 & 0.430 & 0.858 \\
\hline ISEL_17 & 31.80 & 33.177 & 0.473 & 0.856 \\
\hline ISEL_18 & 31.54 & 34.485 & 0.376 & 0.859 \\
\hline ISEL_19 & 31.49 & 34.643 & 0.434 & 0.859 \\
\hline ISEL_20 & 31.74 & 34.026 & 0.326 & 0.860 \\
\hline ISEL_21 & 31.52 & 34.633 & 0.392 & 0.859 \\
\hline ISEL_22 & 31.70 & 34.614 & 0.239 & 0.862 \\
\hline ISEL_23 & 31.53 & 34.387 & 0.443 & 0.858 \\
\hline ISEL_24 & 32.05 & 35.345 & 0.083 & 0.867 \\
\hline ISEL_25 & 31.81 & 35.720 & 0.017 & 0.869 \\
\hline ISEL_26 & 31.55 & 34.072 & 0.491 & 0.857 \\
\hline ISEL_27 & 31.51 & 34.673 & 0.403 & 0.859 \\
\hline ISEL_28 & 31.67 & 34.321 & 0.311 & 0.860 \\
\hline ISEL_29 & 31.76 & 34.058 & 0.325 & 0.860 \\
\hline ISEL_30 & 31.60 & 33.839 & 0.456 & 0.857 \\
\hline ISEL_31 & 31.49 & 34.937 & 0.368 & 0.860 \\
\hline ISEL_32 & 31.55 & 34.200 & 0.466 & 0.858 \\
\hline ISEL_33 & 31.92 & 33.939 & 0.320 & 0.861 \\
\hline ISEL_34 & 31.60 & 33.447 & 0.566 & 0.855 \\
\hline ISEL_35 & 31.57 & 33.737 & 0.551 & 0.856 \\
\hline ISEL_36 & 32.03 & 34.945 & 0.057 & 0.875 \\
\hline ISEL_37 & 31.63 & 33.459 & 0.521 & 0.856 \\
\hline ISEL_38 & 31.59 & 33.802 & 0.495 & 0.856 \\
\hline ISEL_39 & 31.55 & 34.073 & 0.501 & 0.857 \\
\hline ISEL_40 & 31.49 & 35.663 & 0.116 & 0.863 \\
\hline
\end{tabular}

The women researched received relatively high support, obtaining $31.6 \pm 7.13$ points, on average, on the scale from 0 40 points. Characteristic distribution in the researched group was significantly different from the normal distribution. Skewness was $\mathrm{A}=-1.816$, and kurtosis - Kurt $=3.965$.

Low and moderate positive correlations between the subscales of the ISEL- 40 v.GP were found. Criterion validity of the ISEL-40 v.GP was confirmed since negative correlations between the scale and anxiety $(\mathrm{rho}=-0.222 ; \mathrm{p}<0.01)$ and depression $(r h o=-0.272 ; \mathrm{p}<0.01)$ were observed. Correlation matrix between anxiety, depression and support is depicted in Table 5.

Table 5. Correlation matrix between anxiety, depression and social support

\begin{tabular}{lccc}
\hline & Anxiety & Depression & $\begin{array}{c}\text { Support in general } \\
\text { (ISEL-40 v. GP) }\end{array}$ \\
\hline Anxiety & 1 & & \\
\hline Depression & $0.862^{* *}$ & 1 & \\
\hline Support in general (ISEL-40 v. GP) & $-0.222^{* *}$ & $-0.272^{* *}$ & 1 \\
\hline
\end{tabular}

** $-p<0.01$

No statistically significant differences in the perception of social support in individual groups of mothers were found, although mothers of children with cancer were characterized by the lowest level of perceived social support (Tab. 6).

Table 6. Differences in perception of social support in individual groups of mothers

\begin{tabular}{|c|c|c|c|c|}
\hline Support in general & M & SD & $\begin{array}{l}\text { Kruskall-Wallis' } \\
\text { test }\end{array}$ & $\mathrm{p}$ \\
\hline Mothers of children with cancer & 29.92 & 8.86 & \multirow{5}{*}{$\mathrm{H}=7.33$} & \multirow{5}{*}{$p=0.12$} \\
\hline Mothers of children treated in NICU & 33.42 & 4.79 & & \\
\hline Mothers of children treated in PICU & 32.32 & 6.25 & & \\
\hline $\begin{array}{l}\text { Mothers of children with a perinatal } \\
\text { medical history }\end{array}$ & 33.45 & 5.38 & & \\
\hline Mothers of healthy children & 32.07 & 4.46 & & \\
\hline
\end{tabular}

NICU - Neonatal Intensive Care Unit; PICU - Paediatric Intensive Care Unit

\section{DISCUSSION}

Adaptation and validation of the Polish version of the Interpersonal Support Evaluation List, the basic 40-item scale for the general population (ISEL-40 v. GP) was performed almost simultaneously by 2 independent research teams. E. Szlachta surveyed students and office workers and obtained a Cronbach's alpha accuracy coefficient of 0.90 for the entire scale, whereas for the subscale it ranged from $0.69-0.79$. The survey was performed 6 weeks later on the same research sample. Pearson's correlation coefficient for the results of the 
scale and its subscales proved to be statistically significant and its high and moderate values (0.47-0.74) suggest that the measurement was stable in time. Factor analysis according to the orthogonal rotation (Varimax) based on the 4-factor original ISEL-40 was performed in order to check the factorial structure. Obtained factors explained $38 \%$ of the variances (factor I - 12\%, II - 10\%, III - 10\%, and IV - 7\%). Nevertheless, not all positions were correlated with only one factor [35].

Adaptation and psychometric validation of the ISEL-40 v. GP carried out simultaneously by Zarzycka et al. confirmed the tool's high accuracy. In stage I of the research (sample size $n=172$ ) Cronbach's alpha for the entire scale was 0.91, whereas in stage II (retest, sample size $\mathrm{n}=96$ ) Cronbach's alpha was 0.92. Accuracy for the Tangible support subscale was satisfactory, Cronbach's alpha -0.83 and mean correlation between items - 0.63. Accuracy of the Self-esteem support subscale described by Cronbach's alpha coefficient was satisfactory -0.74 , and mean correlation between items of the subscale -0.72 . The Belonging support subscale obtained Cronbach's alpha coefficient of 0.84 and mean correlation between items of 0.84 . Analysis of the results for the Appraisal support subscale showed satisfactory accuracy: Cronbach's alpha - 0.81; mean correlation between items - 0.40 [31].

Internal consistency of the ISEL- $40 \mathrm{v}$. GP obtained in the following research can be assumed as satisfactory (Cronbach's alpha=0.86). Results of internal consistency for the subscales proved to be unsatisfactory since Cronbach' alpha was lower than 0.70 . Even revised versions of the scale, from which items that decreased the scale's consistency were removed, did not obtain satisfactory internal consistency [39]. Thus, it is recommended to use only the social support indicator based on the general result of the ISEL- $40 \mathrm{v}$. GP in scientific research. Comparative analysis of the items from the research results by Zarzycka et al. and the authors' own results points to the items which repeatedly obtained the lowest results in item-scale correlation, namely, 'In general, people do not have much confidence in me; 'There is someone who takes pride in my accomplishments;' 'I am more satisfied with my life than most people are with theirs.' Therefore, a change of the theoretical structure of the subscales in the Polish version of the ISEL-40 v. GP should be considered.

S. Cohen, author of the original scale, proved its correctness by obtaining Cronbach's alpha for the entire scale of 0.87 and for the subscales from 0.67-0.84 [40]. The scale was tested with a 2-time survey of the same group of students at different intervals ( 2 days, 6 weeks and 6 months) by means of a testretest method which made it possible to show consistency in the obtained results (stability with regard to the test). The original version of the scale has proved acceptable criterion validity [30]. Confirmation factor analysis was performed by Brookings and Bolton which proved the ISEL-48 v. GP to be useful for measurement of social support availability that fits the 4-factor data. The RMSEA coefficient for factor models ranges from $0.05-0.07$. The high correlations between subscales may suggest the possibility of utilizing a onedimension scale which involves loss of unique information of an assessing-appreciating character, carried by factors of the lowest orthogonality [41]. In the research on elderly people with depressed mood, a 4-factor structure of the original version of the ISEL-40 v. GP and high internal consistency (Cronbach's alpha 0.95) was found [42]. The ISEL-40 v. GP was proved [43] a very good predictive power in longitudinal research on patients with spine injuries. The ISEL-4 v. GP is compared primarily to the ISEL- 48 v. Coll., which is dedicated for measurement of social support in students, and the ISEL-12, a short version of the scale [44]. Currently, the ISEL-40 v. GP has 9 versions, namely, the original English version, and versions in Polish, Greek, Belgian, Danish, Japanese, Swedish, Serbian and Spanish. The adaptations and psychometric validations performed point to moderate and good indicators of internal consistency: the Greek version - Cronbach's alpha 0.45-0.75 [45], Serbian version - Cronbach's alpha 0.78 [46].

Summing-up, the Polish adaptation of the ISEL-40 v. GP turned out to share a common problem typical of the scales which involves assigning certain elements to a given factorial structure or concept. Tests, commonly recognized as 'golden standards', such as the HADS, also have some questionable factorial structure [47]. The problem of factorial structure of the ISEL-40 becomes relative if the tool is used for measuring the global resource of social support.

Initial results of the authors' own research, which determined social support in mothers - a group of particular characteristics in terms of providing and seeking support, indicate a lack of diversity of support with regard to the children's state of health. However, it was observed that the mothers of children with cancer perceive the lowest mean social support, which is quite varied $(\mathrm{M}=29.92 ; \mathrm{SD}=8.86)$. Some sparse results show that, in general, parents of children with cancer tend to seek and thus receive less support compared to the parents of healthy children [48]. Situational and psychological problems of the parents correlate with the moment of their child's treatment and the time since the diagnosis and affect their positive emotional spiritual coping and the level of optimism, which is also determined by social support [49]. A low level of social support in parents is connected with experiencing depressed mood and accompanying emotional states [50]. Parents of children suffering from chronic illnesses, mothers in particular (90\%), rate social support provided to them as insufficient. The most significant source of support for the parents of ill children is family support (54\%). Informational support from the medical staff is insufficient among the parents of children with a diagnosis of neurological disease [51], although it is present in the group of parents of children with cancer [52]. Therefore, diagnosis of the availability of social support in the mothers and supporting them in a deliberate, comprehensive and individualized way is recommended [53].

\section{CONCLUSIONS}

1. The Polish adaptation of the ISEL-40 v. GP has a high indicator of internal consistency in a group of mothers of healthy children and those with a medical history, which suggests reliable research results and diagnostic accuracy in scientific research.

2. It is recommended to use the general result of the ISEL$40 \mathrm{v}$. GP in the measurement of social support in the mothers.

3. Social support for the mothers is on a moderate level and the children's health state does not affect the perception of support. 


\section{REFERENCES}

1. Tanskanen J, Anttila T. A prospective study of social isolation, loneliness, and mortality in Finland. AJPH 2016; 106(11): 2042-2048. doi: 10.2105/AJPH.2016.303431.

2. Holt-Lunstad J, Smith TB, Baker M, Harris T, Stephenson D. Loneliness and social isolation as risk factors for mortality: A meta-analytic review. Perspect Psychol Sci. 2015; 10(2): 227-237. https://doi. org/10.1177/1745691614568352.

3. Barth J, Schneider S, Von Känel R. Lack of social support in the etiology and the prognosis of coronary heart disease: A systematic review and meta-analysis. Psychosom Med. 2010;72(3):229-238.

4. Holt-Lunstad J, Smith TB, Layton JB. Social relationships and mortality risk: A meta-analytic review. PLoSMed. 2010; 7(7): e1000316. http://doi. org/10.1371/journal.pmed.1000316.

5. Reblin M, Uchino BN. Social and emotional support and its implication for health. Curr Opin Psychiatry. 2008; 21(2): 201-205. http://doi. org/10.1097/YCO.0b013e3282f3ad89.

6. Valtorta NK, Kanaan M, Gilbody S, Ronzi S, Hanratty B. Loneliness and social isolation as risk factors for coronary heart disease and stroke: systematic review and meta-analysis of longitudinal observational studies. Heart 2016; 102(13), 1009-1016. http://doi.org/10.1136/ heartjnl-2015-308790.

7. Rzeszutek M, Oniszczenko W, Firląg-Burkacka E. Social support, stress coping strategies, resilience and posttraumatic growth in a Polish sample of HIV-infected individuals: results of a 1 year longitudinal study. Int J Behav Med. 2017; 40(6): 942-954.

8. Uchino BN. Social support and health: A review of physiological processes potentially underlying links to disease outcomes. J Behav Med. 2006; 29(4): 377-387. http://doi.org/10.1007/s10865-006-9056-5.

9. Matsumoto S, Yamaoka K, Takahashi K, Tanuma J, Mizushima D Do et al. Social Support as a Key Protective Factor Against Depression in HIV-Infected Patients: Report from large HIV clinics in Hanoi, Vietnam 2017. Scientific Reports, 7, 15489. http://doi.org/10.1038/ s41598-017-15768-w.

10. Kelly ME, Duff H, Kelly S, McHugh Power, JE, Brennan S, Lawlor BA et al. The impact of social activities, social networks, social support and social relationships on the cognitive functioning of healthy older adults: a systematic review. Syst Rev. 2017; 6(1): 259. http://doi.org/10.1186/ s13643-017-0632-2.

11. Uchino BN, Bowen K, Carlisle M, Birmingham W. Psychological pathways linking social support to health outcomes: A visit with the "Ghosts" of Research Past, Present, and Future. Soc Sci Med. 2012; 74(7): 949-957. http://doi.org/10.1016/j.socscimed.2011.11.023.

12. Thoits PA. Mechanisms linking social ties and support to physical and mental health. J Health Soc Behav. 2011; 52(2): 145-161.https://doi. org/10.1177/0022146510395592

13. Walker RJ, Gebregziabher M, Martin-Harris B, Egede LE. Relationship between social determinants of health and processes and outcomes in adults with type 2 diabetes: validation of a conceptual framework.BMC Endocr Disord. 2014; 14:82. http://doi.org/10.1186/1472-6823-14-82.

14. Jeong A, An JY. The moderating role of social support on depression and anxiety for gastric cancer patients and their family caregivers. PLoS ONE. 2017; 12(12): e0189808, doi: 10.1371/journal.pone.0189808.

15. Matcham F, Ali S, Hotopf M, Chalder T. Psychological correlates of fatigue in rheumatoid arthritis: A systematic review. ClinPsychol Rev. 2015; 39:16-29. doi: 10.1016/j.cpr.2015.03.004.

16. Barskova T, Oesterreich R. Post-traumatic growth in people living with a serious medical condition and its relations to physical and mental health: A systematic review. Disabil Rehabil. 2009; 31:1709-1733, doi: 10.1080/09638280902738441

17. Dennison L, Moss-Morris R, Chalder T. A review of psychological correlates of adjustment in patients with multiple sclerosis. Clin Psychol Rev. 2009; 29(2): 141-53. doi: 10.1016/j.cpr.2008.12.001. Epub 2008 Dec 16.

18. Utz S, Breuer J. The relationship between use of social network sites, Online Social Support, and Well-Being: Results From a Six-Wave Longitudinal Study. J Media Psychol. 2017; 29(3): 115-125. http://doi. org/10.1027/1864-1105/a000222.

19. Motzer SA, Hertig V. Stress, stress response, and health. NursClin North Am. 2004; 39(1): 1-17.

20. Taylor SE, Klein LC, Lewis BP, Gruenewald TL, Gurung RAR, Updegraff JA. Biobehavioral responses to stress in females: Tend-and-befriend, not fight-or-flight. Psychol Rev. 2000; 107(3): 411-429. doi:10.1037/0033295X.107.3.411.

21. Molesztak A. [Support and psychological gender in females and males - a research report. Culture - Society - Education 2016] Wsparcie i płeć psychologiczna kobiet i mężczyzn - raport z badań. Kultura - Społeczeństwo - Edukacja 2016; 2(10): 151-162, doi: 10.14746/ kse.2016.10.12.

22. Kajantie E, Phillips DI. The effects of sex and hormonal status on the physiological response to acute psychosocial stress. Psychoneuroendocrinology. 2006; 31(2): 151-78.

23. Tifferet S, Manor O, Constantini S, Friedman O, Elizur Y. Sex differences in parental reaction to pediatric illness. J Child Health Care. 2011; 15(2): 118-25. doi: 10.1177/1367493510397710.

24. Aftyka A, Rozalska-Walaszek I, Wróbel A, Bednarek A, Dąbek K, Zarzycka D. Support provided by nurses to parents of hospitalized children - cultural adaptation and validation of Nurse Parent Support Tool and initial research results. Scand J Caring Sci; 2017; 31(4): 10121021.

25. Pennafort VP, Queiroz MV, Nascimento LC, Guedes MV. Network and social support in family care of children with diabetes. Rev Bras Enferm. 2016; 69(5): 912-919. doi: 10.1590/0034-7167-2015-0085.

26. Marcinowicz L, Abramowicz P, Zarzycka D, Abramowicz M, Konstantynowicz J. How hospitalized children and parents perceive nurses and hospital amenities: a qualitative descriptive study in Poland. Child Health Care. 2016; 20(1): 120-128.

27. Carlson JM, Miller PA. Family burden, child disability, and the adjustment of mothers caring for children with epilepsy: Role of social support and coping. Epilepsy Behav. 2017; 68: 168-173. doi: 10.1016/j. yebeh.2017.01.013.

28. van Driessche A, Jotheeswaran AT, Murthy GV, Pilot E, Sagar J, Pant $\mathrm{H}$ et al. Psychological well-being of parents and family caregivers of children with hearing impairment in south India: influence of behavioural problems in children and social support. Int Rev Psychiatry. 2014; 26(4): 500-7. doi: 10.3109/09540261.2014.926865.

29. Cohen S, Hoberman HM. Positive events and social supports as buffers of life change stress. J Community ApplSoc Psychol. 1983; 13(2): 99-125.

30. Cohen S, Mermelstein R, Kamarck T, Hoberman HM. Measuring the functional components of social support. In: Sarason IG, Sarason BR, editors. Social Support: Theory, Research and Applications. Martnus Nijhoff Publishers. Dordrecht/Boston/Lancaster; 1985. p. 73-94.

31. Cohen's Scales. http://www.psy.cmu.edu/ scohen/\&ei access: 16.01.2018.

32. Cohen S, McKay, G. Social support, stress and the buffering hypothesis: A theoretical analysis. In: Baum A, Taylor SE, Singer JE editors. Handbook of Psychology and Health. Hillsdale NJ: 198. 1984; p. 255-260.

33. Cohen S, Pressman S. Stress - buffering hypothesis. In: Anderson NB, editors. Encyclopedia of Health \& Behavior. Sage Publications. APA 2004; p. 780-782.

34. Zarzycka D, Śpila B, Wrońska I, Makara-Studzińska M. Validation analysis of selected aspects of Interpersonal Support Evaluation List 40 v. General Population (ISEL-40 v. GP) Psychiatria 2010; 7(3): 83-94.

35. Szlachta E. The Adaptation and Preliminary Validation of the Polish Version of the Interpersonal Support Evaluation List (ISEL). Prz Psychol. 2009; 52(4): 433-451.

36. Zigmond AS, Snaith RP. The Hospital Anxiety and Depression Scale. Acta Psychiatr Scand. 1983; 67(6): 361-370. doi:10.1111/j.1600-0447.1983. tb09716.x.

37. Watrowski R, Rohde A. Validation of the Polish version of the Hospital Anxiety and Depression Scale in three populations of gynecologic patients. AMS 2014;10(3): 517-524. http://doi.org/10.5114/ aoms.2013.36520.

38. Majkowicz M. [Practical evaluation of palliative care effectiveness selected research techniques] Praktyczna ocena efektywności opieki paliatywnej - wybrane techniki badawcze. In: de Walden-Gałuszko $\mathrm{K}$, Majkowicz M, editors. [Evaluation of palliativecareeffecticeness in theory and practice] Ocena jakości opieki paliatywnej w teorii i praktyce [Polish] Gdańsk: Akademia Medyczna; 2000. p. 34-36.

39. Bedyńska S, Cypryańska M. [Advanced methods of developing indicators - exploratory factor analysis and testing reliability of a scale.] Zaawansowane metody tworzenia wskaźników - eksploracyjna analiza czynnikowa i testowanie rzetelności skali. In: Bedyńska S, Cypryańska M, editors. [Statistical signpost. Practical introduction to statistical inference.] Statystyczny drogowskaz. Praktyczne wprowadzenie do wnioskowania statystycznego. Wydawnictwo akademickie Sedno Spółka z o. o., Warszawa 2013; p. 245-283.

40. Cohen S, Underwood LG, Gottlieb BH. (Eds). Social Suppor and Intervention. A Guide for Health and Social Scientists. Oxford University Press, New York 2000.

41. Brookings JB, Bolton B. Confirmatory factor analysis of the Interpersonal Support Evaluation List. Am J Community Psychol. 1988; 16: 137-147. 
42. Ghesquierea A, Schwartzb T, Wangc Y, Mauroc C, Skritskayad $\mathrm{M}$, Sheare NK. Performance and psychometric properties of the Interpersonal Support Evaluation List (ISEL) in older adults with Complicated Grief. J. Affect. Disord. 2017; 15(218), 388-393. https:// doi.org/10.1016/j.jad.2017.05.004

43. Rintala DH. Predictive validity of social support relative to psychological well-being in men with spinal cord injury. Rehabil Psychol. 2013; 58(4): 422-428. http://dx.doi.org/10.1037/a0034357

44. Zarzycka D, Ślusarska B, Dyk D, Bednarek A, Trojanowska A. Polish adaptation of Interpersonal Support Evaluation List, a version for students (ISEL-48v.Coll.: Interpersonal Support Evaluation List College Version). Health Prob Civil. 2017; 11(3): 280-286. doi: https:// doi.org/10.5114/hpc.2017.71889.

45. Dalistamati E, Samacouri M, Davis E. Vorvolacos T, Xenitidis K Livaditis M. Interpersonal Support Evaluation List (ISEL) - College Version: validation and application in Greek sample. Int J Soc Psychiatry 2006; 52(6): 552-560. https://doi.org/10.1177/0020764006074184.

46. Jaredić B, Hinić D, Stanojević D, Zečević S, Ignjatović-Ristić D. Affective temperament, social support and stressors at work as the predictors of life and job satisfaction among doctors and psychologists. Vojnosanit Pregl. 2017; 74(3): 241-248. doi: 10.2298/VSP151020183J.

47. Bagby RM, Ryder AG, Schuller DR, Marshall MB. The Hamilton Depression Rating Scale: has the gold standard become a lead weight? Am J Psychiatry 2004; 161: 2163-2177.
48. Fotiadou M, Barlow JH, Powell LA, Langton H. Optimism and psychological well-being among parents of children with cancer: an exploratory study. Psychooncology 2008; 17(4): 401-409.

49. Gardner MH, Mrug S, Schwebel DC, Phipps S, Whelan K, MadanSwain A. Demographic, medical, and psychosocial predictors of benefit finding among caregivers of childhood cancer survivors. PsychoOncology 2017; 26(1): 125-132. http://doi.org/10.1002/pon.4014.

50. Chrapek E. [Psychological challenges, social support and coping in parents of children with cancer.] Psychologiczne trudności, wsparcie społeczne oraz radzenie sobie ze stresem u rodziców dzieci z chorobą nowotworową. Psychiatr Psychol Klin 2016; 16(1):27-32. doi: 10.15557/ PiPK.2016.0005.

51. Grzegorczyk A, Szewczyk L. [Evaluation of social support in parents of children with neurological conditions. Aspects of Health and Disease.] Ocena wsparcia społecznego rodziców dzieci z chorobami neurologicznymi. Aspekty Zdrowia i Choroby. 2016; 1(4): 55-64.

52. Cepuch G, Krupa A, Wojtas K. [Coping and social support in parents of children with a life-threatening disease.] Radzenie sobie ze stresem i wsparcie społeczne rodziców dzieci z chorobą zagrażającą życiu. Onkol Pol. 2011; 14(4): 174-181.

53. Crane PA, Constantino RE. Use of the Interpersonal Support Evaluation List (ISEL) to guide intervention development with women experiencing abuse. Ment Health Nurs. 2003; 24(5): 523-541. 